\title{
Differential growth response of green and variegated Ficus benjamina to exogenous cytokinin and shade
}

\author{
Adalberto Di Benedetto ${ }^{1,2^{*}}$, Claudio Galmarini ${ }^{3,4}$, Jorge Tognetti2,5
}

\begin{abstract}
Benjamin fig (Ficus benjamina) is an important foliage and landscape crop species comprising green and variegated genotypes. The latter develop leaves with yellow and white leaf areas which may impose lower photosynthetic activity, thus resulting in slower growth than green genotypes. In many species, the exogenous supply of cytokinin to pot-grown plants promotes growth, mainly due to enhanced carbon fixation. In this work, we analyze the effect of spraying the cytokinin 6-benzylaminopurine (BAP) on growth and development of green and variegated Ficus benjamina genotypes. Two experiments were carried out in a greenhouse, in which either different number of BAP applications (Experiment 1) or different BAP concentrations (Experiment 2) were tested. In Experiment 2, plants were grown under three different light intensities. BAP sprays promoted rate of leaf appearance, leaf expansion and whole-plant growth, and the effect was stronger in variegated than in green plants. The relative growth rate promotion by BAP was associated with increased net assimilation rate rather than with variation in the leaf area ratio. On the other hand, shading had a more negative impact on growth and development of variegated plants than in green ones. Variegated plants, unlike green ones, developed leaves with high specific leaf area under the lowest light intensity. This led to high leaf area ratio values, which helped to maintain relative growth rates close to those of plants under moderate shading.
\end{abstract}

Keywords: Ficus benjamina, growth regulator, leaf growth, ornamental foliage plants, variegated plant.

\section{Resumo}

Diferentes respostas de crescimento de Ficus benjamina verde e variegado à citocinina exógena e sombreamento O Ficus (Ficus benjamina) é uma importante espécie de folhagem usada no paisagismo que compreende genótipos verdes e variegados. Estes últimos desenvolvem folhas com áreas foliares amarelas e brancas que podem impor menor atividade fotossintética, resultando em crescimento mais lento que os genótipos verdes. Em muitas espécies, o suprimento exógeno de citocinina em plantas cultivadas em vaso promove o crescimento, principalmente devido à maior fixação de carbono. Neste trabalho, analisamos o efeito da pulverização da citocinina 6-benzilaminopurina (BAP) no crescimento e desenvolvimento de genótipos verdes e variegados de Ficus benjamina. Foram realizadas dois experimentos em casa de vegetação, nos quais foram testados diferentes números de aplicações de BAP (Experimento 1) ou diferentes concentrações de BAP (Experimento 2). No experimento 2, as plantas foram cultivadas sob três intensidades de luz diferentes. A pulverização com BAP promoveram taxa de aparência foliar, expansão foliar e crescimento de plantas inteiras, e o efeito foi mais forte em variegadas do que em plantas verdes. A promoção da taxa de crescimento relativo pelo BAP foi associada ao aumento da taxa líquida de assimilação, e não à variação na proporção da área foliar. Por outro lado, o sombreamento teve impacto mais negativo no crescimento e desenvolvimento de plantas variegadas do que nas verdes. Plantas variegadas, diferentemente das verdes, desenvolveram folhas com alta área foliar específica sob a menor intensidade de luz. Isso levou a altos valores da razão de área foliar, o que ajudou a manter taxas de crescimento relativas próximas às das plantas sob sombreamento moderado.

Palavras-chave: Ficus benjamina, regulador de crescimento, crescimento foliar, plantas ornamentais de folhagem, planta variegada.

\footnotetext{
${ }^{1}$ Universidad de Buenos Aires, Facultad de Agronomía, Buenos Aires, Argentina. *Corresponding author: dibenede@agro.uba.ar

${ }^{2}$ Universidad Nacional de Mar del Plata, Facultad de Ciencias Agrarias, Balcarce, Argentina.

${ }^{3}$ Universidad Nacional de Cuyo and CONICET, Facultad de Ciencias Agrarias, Chacras de Coria, Argentina.

${ }^{4}$ Instituto Nacional de Tecnología Agropecuaria EEA La Consulta, San Carlos, Argentina.

${ }^{5}$ Comisión de Investigaciones Científicas de la Provincia de Buenos Aires, La Plata, Argentina.
}

Received Aug 30, 2019| Accepted May 1'st, 2020 | Available online May 26, 2020

Licensed by CC BY 4.0

https://doi.org/10.1590/2447-536X.v26i2.2089

Area Editor: Fernanda Carlota Nery 


\section{Introduction}

Ficus is a genus comprising more than 800 species that includes Benjamin fig (Ficus benjamina), widely used as an ornamental foliage potted plant, which takes part of urban tree planting programs in many countries. Significant differences in growth rate among clones are known to occur, and these differences tend to increase during plant development. Particularly valuable ornamental clones are the 'variegated' ones, whose leaves are partially yellow or white (Shih et al., 2019). These leaf zones may contain virtually no chlorophyll or photosynthetic enzymes and consequently present extremely low photosynthetic activity (Zhang et al., 2018). Although detailed studies to compare growth of green vs variegated Ficus cultivars have not been performed yet, work on other species suggests that growth rates of variegated cultivars may be substantially lower than those of completely green ones (Veneklaas et al., 2002).

Besides genotypic differences, environmental constrains such as small pot size and low irradiance often affect $F$. benjamina growth at production sites and at indoor locations. Reduced rooting volume may represent a major growth-limiting factor in $F$. benjamina (Di Benedetto et al., 2010). This could be associated with an insufficient cytokinin production and transport from roots, since plant root apices are the main source of the hormone at a wholeplant level (Daviere and Achard, 2017; Duran-Median et al., 2017; Di Benedetto et al., 2018). Cytokinins promote leaf greening through enhanced chloroplast development and chlorophyll accumulation (Cortleven and Schmülling, 2015), and promote nitrogen partitioning to leaves (Gu et al., 2018), ultimately resulting in increased carbon fixation rates (Di Benedetto et al., 2015b). Early exogenous applications of the cytokinin 6-benzylaminopurine (BAP) on pot-raised plants effectively promoted growth in several ornamental species (De Lojo and Di Benedetto, 2014; Di Benedetto et al., 2015a, b). In terms of growth analysis parameters, exogenous BAP promoting effect on the relative growth rate (RGR) (Pal et al., 2018) was due to result from a large positive impact on the net assimilation rate (NAR) (Moualeu-Ngangue et al., 2017), being this parameter associated with leaf carbon fixation. On the other hand, in experiments with pothos (Epipremnum aureum) (Di Benedetto et al., 2015a) showed that BAP resulted in somewhat lower LAR values due to the development of thicker leaves and therefore lower values of specific leaf area (SLA), one of the components of the leaf area ratio (LAR). It is uncertain how BAP may affect SLA and LAR of green and variegated Ficus genotypes, but it has been shown in other species that variegated genotypes generally present higher LAR values than green ones.

Low irradiance is another major factor that permits ornamental plants growth at indoor locations. Under these conditions, F. benjamina development may be significantly delayed, resulting in longer duration of the cultivation period. Low light levels may differentially affect green and variegated genotype development (Scuderi et al., 2013). It has been suggested that leaf variegation is a naturally evolved feature that allows light reflection, thus allowing a better illumination in inner canopy zones, at a rather low energetic cost (Chen et al., 2017). According to Konoplyova et al. (2008), variegation may be useful under higher light intensities, while on the contrary, dark green leaves (and completely green genotypes) may be more efficiently adapted to low irradiances. It seems that leaf variegation, cytokinin levels and irradiance are closely intertwined in determining plant growth. The pattern in which these factors interact in $F$. benjamina development has not been addressed yet. Knowledge about the relationships among these factors is needed given the fact that $F$. benjamina is an important ornamental crop worldwide. In the present work, we study the effect of exogenous BAP supply at different number of applications, or at different concentrations under three light intensities, on the development of green and variegated genotypes of pot-grown $F$. benjamina plants, and analyze the physiological processes involved in plant responses.

\section{Materials and Methods}

Two experiments were carried out in a greenhouse located at the Faculty of Agronomy, University of

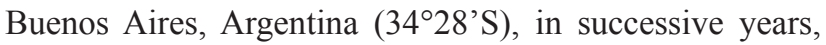
from September $8^{\text {th }} 2014$ to March $11^{\text {th }} 2015$, and from September $7^{\text {th }} 2015$ to March $11^{\text {th }} 2016$ (Experiments 1 and 2 , respectively).

Rooted cuttings of 'green' and 'variegated' F. benjamina genotypes were obtained from a commercial propagator (Vivero Kogiso, Buenos Aires, Argentina). At the transplant stage, whole-plant fresh biomasses of green and variegated cuttings were not significantly different, having attained $2.04 \pm 0.17$ (green) or $1.90 \pm 0.19$ (variegated) g cutting $^{-1}$ in Experiment 1, and $3.4 \pm 0.34$ (green) or $4.46 \pm 0.53$ (variegated) $\mathrm{g}_{\text {cutting }}{ }^{-1}$ in Experiment 2.

Rooted cuttings were transplanted into rigid 1,200$\mathrm{cm}^{3}$ plastic pots (one plant per pot). The pots were filled with a 40-40-20 (v/v/v) mix of Sphagnum maguellanicum peat: river waste: perlite. River waste or 'temperate peat' is the result of the accumulation of plant residues under an anaerobic environment, which is dredged from river or lake banks placed under a subtropical climate with high rainfalls over 1,000 mm (Di Benedetto and Klasman, 2007).

Plants were watered daily to saturation with high quality tap water $\left(\mathrm{pH}=6.64\right.$; electrical conductivity $\left.=0.486 \mathrm{dS} \mathrm{m}^{-1}\right)$ and were fertilized each week with $50 \mathrm{mg} \mathrm{L}^{-1} \mathrm{~N}$ as 1.0: 0.5: 1.0: $0.5(\mathrm{v} / \mathrm{v} / \mathrm{v} / \mathrm{v}) \mathrm{N}$ : P: K: Ca (nitric acid, phosphorus acid, potassium nitrate and calcium nitrate; Agroquímica Larocca S.R.L., Buenos Aires, Argentina) via overhead fertigation.

The greenhouse was divided into three blocks for statistical sampling. In Experiment 1, the greenhouse was covered with a black shade-cloth to obtain $70 \%$ full-sunlight. For Experiment 2, within each block, three compartments with different neutral shading cloths were defined, in order to obtain irradiance levels equivalent to $70 \%, 50 \%$ or $30 \%$ of full-sunlight. The red: far-red ratio was not significantly modified by the shade-cloth, as checked with a 660/730 sensor (Skye Instruments, Wales, UK). Mean temperatures and light intensities during the experiment 
were recorded with HOBO sensors (H08-004-02) (Onset Computer Corporation, MA, USA) connected to a HOBO $\mathrm{H} 8$ data logger. Air temperatures ranged between 12.68$20.69^{\circ} \mathrm{C}$ (minimum) and $21.38-30.62^{\circ} \mathrm{C}$ (maximum) during Experiment 1 and between $10.48-20.60^{\circ} \mathrm{C}$ (minimum) and $18.63-31.13^{\circ} \mathrm{C}$ (maximum) during Experiment 2. Shading treatments did not significantly affect temperature within greenhouse sections. Solar radiation ranged between 6.34 and $10.99 \mathrm{MJ} \mathrm{m}^{-2}$ day $^{-1}$ in Experiment 1, and between 5.93 and $11.79 \mathrm{MJ} \mathrm{m}^{-2}$ day $^{-1}$ in Experiment 2.

In Experiment 1, plants were subjected to different number of BAP applications, by spraying them with zero (i.e, distilled water control) or $5 \mathrm{mg} \mathrm{L}^{-1}$ BAP solutions (Sigma-Aldrich Co., St. Louis, MO, USA) at different times. Applications were performed once (7 days after transplant), twice ( 7 and 30 days after transplant) or three times $(7,30$, and 60 days after transplant) rendering three different BAP treatments, i.e., 5-0-0, 5-5-0 and 5-5-5 mg $\mathrm{L}^{-1} \mathrm{BAP}$, and a water control (0-0-0 $\left.\mathrm{mg} \mathrm{L}^{-1} \mathrm{BAP}\right)$. The BAP concentration was chosen from the results of a preliminary experiment. In Experiment 2, plants were sprayed with zero (control), 2.5, 5, 10, or $50 \mathrm{mg} \mathrm{L}^{-1}$ BAP solutions 7 days after transplanting. In both experiments, all leaves were sprayed to run-off at sunset (approximately $50 \mathrm{ml} \mathrm{pot}^{-1}$ ). BAP was first diluted in $80 \%$ (mL per liter) ethanol and no surfactants were added.

At each harvest, two plants per block and treatment were destructively sampled. Plants were dissected into leaf blades, petioles, and stems, to obtain fresh weights (FW). Dry weights (DW) was assessed obtained after drying to constant weight, at $80^{\circ} \mathrm{C}$ for 96 hours. Dry matter content (DMC) of leaf blades was calculated as $100 * \mathrm{DW} / \mathrm{FW}$. Individual leaf area was determined using a LI-COR 3000A automatic leaf area meter (LI-COR Inc., Lincoln, NE, USA). The number of appeared leaves was recorded only in Experiment 2.

Plant growth analysis was performed on data from Experiment 2. Plants were sampled at 0, 60, 90, 120 and 160 days after transplanting. The relative leaf-areaexpansion rate (RLAER), the rate of leaf appearance
(RLA), the relative growth rate (RGR), the net assimilation rate (NAR), the leaf area ratio (LAR), the specific leaf area (SLA) and leaf weight ratio (LWR) on a dry weight (DW) basis were calculated according to Di Benedetto and Tognetti (2016).

Chemical analyses were performed on young fully expanded leaf blades, at the last harvest of Experiment 2. Total soluble carbohydrate (TSC) concentration was analysed using the phenol-sulphuric method. Nitrogen concentration was analysed by the Kjeldall method. Chlorophyll content was extracted used N, N-dimethyl formamide.

The experimental design was a randomized factorial with four BAP applications on two $F$. benjamina genotypes for experiment 1 and four BAP concentrations, three light environments and two genotypes for experiment 2. For both experiments, thirty plants were used and they were sprayed and distributed at random within three blocks (ten plants per block). Data were subjected to two-way and threeway analysis of variance (ANOVA) using STATISTICA 8 software (StatSoft) after checking ANOVA assumptions for experiment 1 and 2 respectively. Means were separated by Tukey's tests $(p \leq 0.05)$. Slopes from straight-line regressions were tested using the SMATR package.

\section{Results and Discussion}

Untreated green plants achieved more fresh and dry biomass, and up to a lesser extent, more total plant leaf area, than variegated ones at the end of Experiment 1 (Figures 1A, $\mathrm{B}$ and 2). A single BAP spray was enough to significantly increase total FW (Figure 1A) and total leaf area (Figure 1B) over control plants in both green and variegated $F$. benjamina genotypes. The increase in fresh weight by a single BAP spray was more pronounced in variegated plants than in green ones, resulting in no significant differences between genotypes in FW at harvest (Figure 1A). Additional sprays tended to increase plant response to the hormone in the green genotype, while no further promotion in the variegated one was observed by increasing the number of BAP applications (Figures 1A, B).
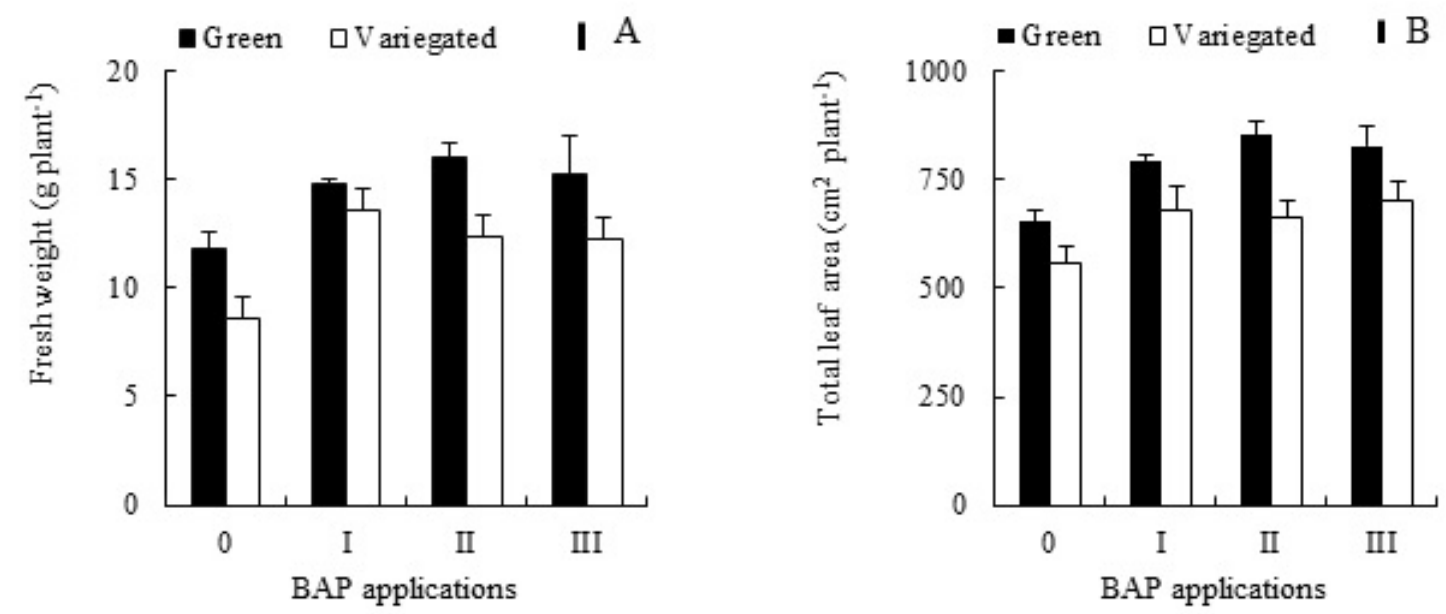

Figure 1. Total fresh weight (A) and total leaf area (B) at the end of the 2013-2014 experiment in 'green' and 'variegated' Ficus benjamina plants sprayed with either 0 or $5 \mathrm{mg} \mathrm{L}^{-1}$ BAP solutions at different times (I-II-III: one, two or three monthly sprays). Bars indicate standard errors. Least significant differences (LSD) values were calculated. 
BAP sprays also led to a higher dry mass accumulation in every plant part (Figures 2A, B). Dry mass of above ground organs increased more than roots dry matter, leading to a decrease in the root: shoot ratio of BAP-treated plants in comparison with controls. This decrease tended to be more pronounced with repeated BAP applications. Under every BAP treatment, green plants had significantly higher root: shoot ratios than variegated ones (Figure $2 \mathrm{C}$ ).
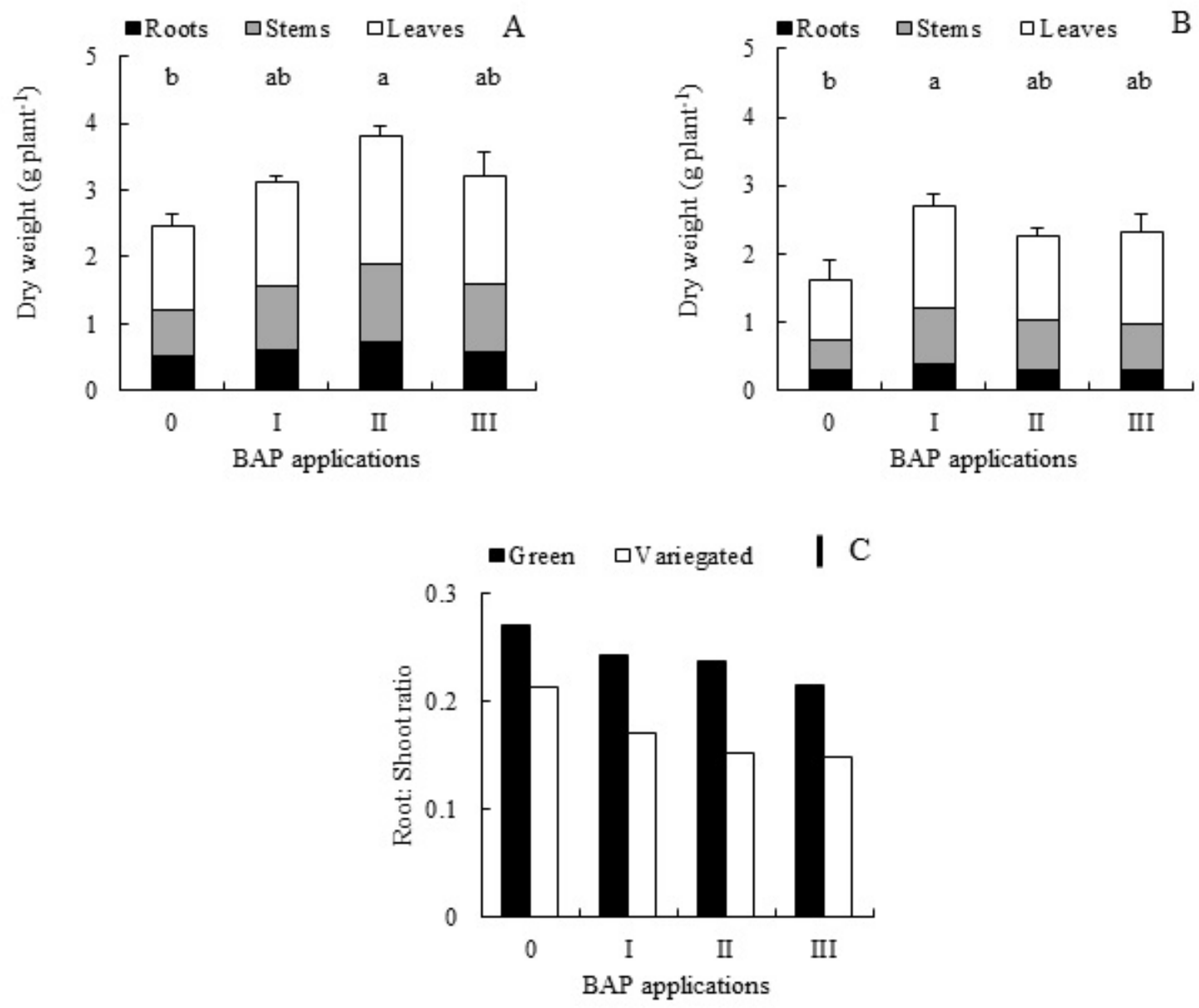

Figure 2. Total dry weight at the end of the 2013-2014 experiment in 'green' (A) and 'variegated' (B) Ficus benjamina plants sprayed with either 0 or $5 \mathrm{mg} \mathrm{L}^{-1}$ BAP solutions at different times (I-II-III: one, two or three monthly sprays). Bars indicate standard errors. Different lower case letters indicate significant differences $(\mathrm{P}<0.05)$. Plate $\mathrm{C}$ indicates root: shoot ratio. Least significant differences (LSD) values were calculated.

In Experiment 2, untreated green plants achieved about $20 \%$ more fresh biomass at final harvest than variegated ones, irrespective of light intensity (Figures $3 \mathrm{~A}, \mathrm{~B})$. Differences in dry mass between genotypes were somewhat higher (around 30\%; Figures 4A, B), while differences in leaf area were observed only under the two lowest light intensities (Figures 3C, D). In both genotypes, BAP application at any concentration significantly increased whole plant $\mathrm{FW}$ and leaf area (Figures 3C, D). At the lowest light intensity, plants were much smaller and the effect of BAP was less marked, although a similar trend could be observed under higher irradiances (Figures 3A, B). Dry mass accumulation was also promoted by BAP, but not all plant parts behaved similarly, being shoot mass accumulation more promoted than that of roots (Figures 4A, B). As a consequence, a decrease in the root: shoot ratio of BAP-treated plants, in comparison with controls, was observed, for both genotypes (Figures 4C, D). In many cases, green plants had significantly higher root: shoot ratios than variegated ones, but differences between genotypes were smaller under the lowest light intensity. The negative impact of cytokinins on root development is a well-known effect of this hormone (Di Benedetto et al., 2020a, b). 

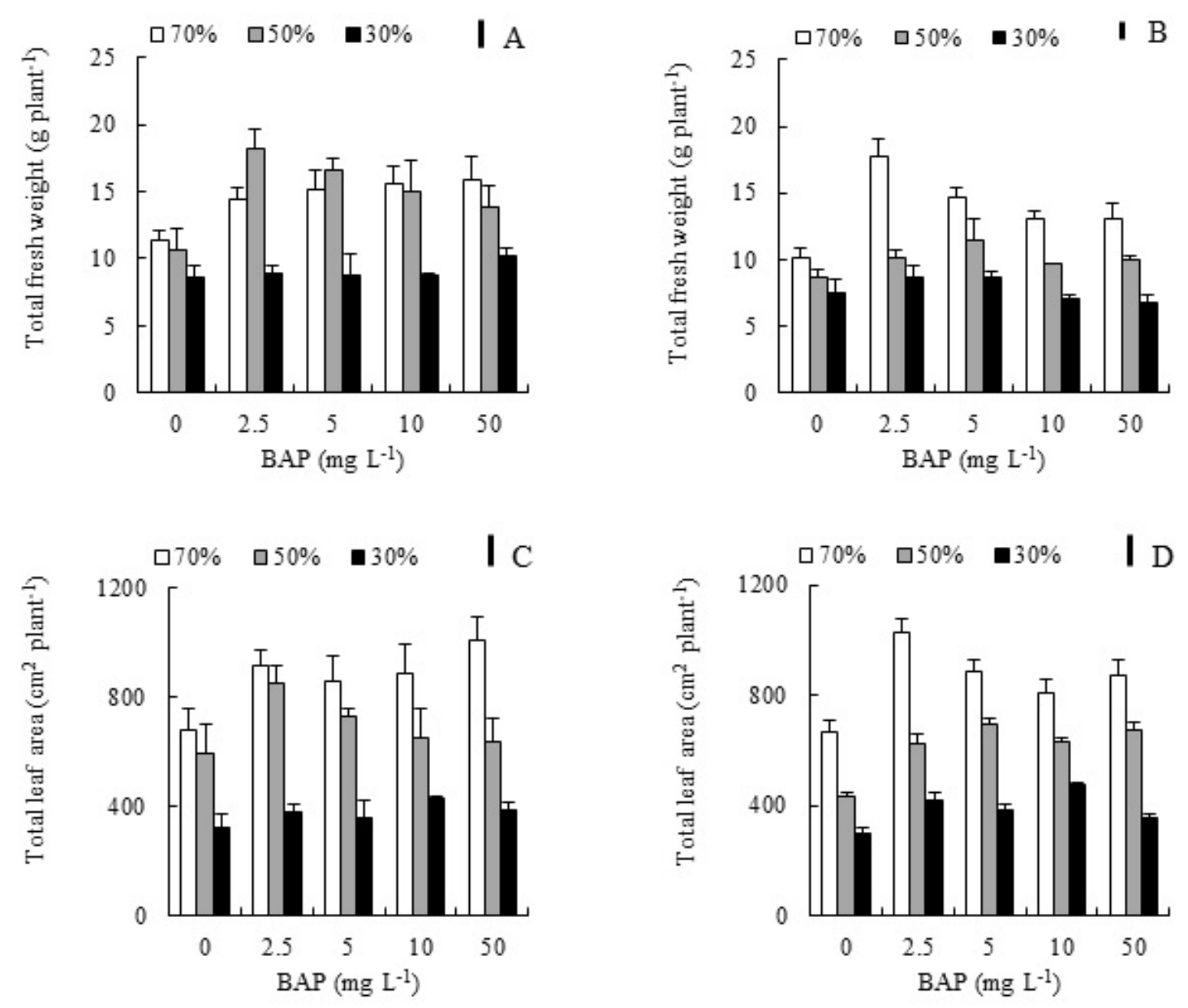

Figure 3. Total fresh weight and total leaf area during the 2014-2015 experiment in 'green' (A and C) or 'variegated' (B and D) Ficus benjamina plants grown under three light intensities: 70\%, 50\% and 30\% full sunlight, and sprayed with different BAP concentrations. Bars indicate standard errors. Least significant differences (LSD) values were calculated. 

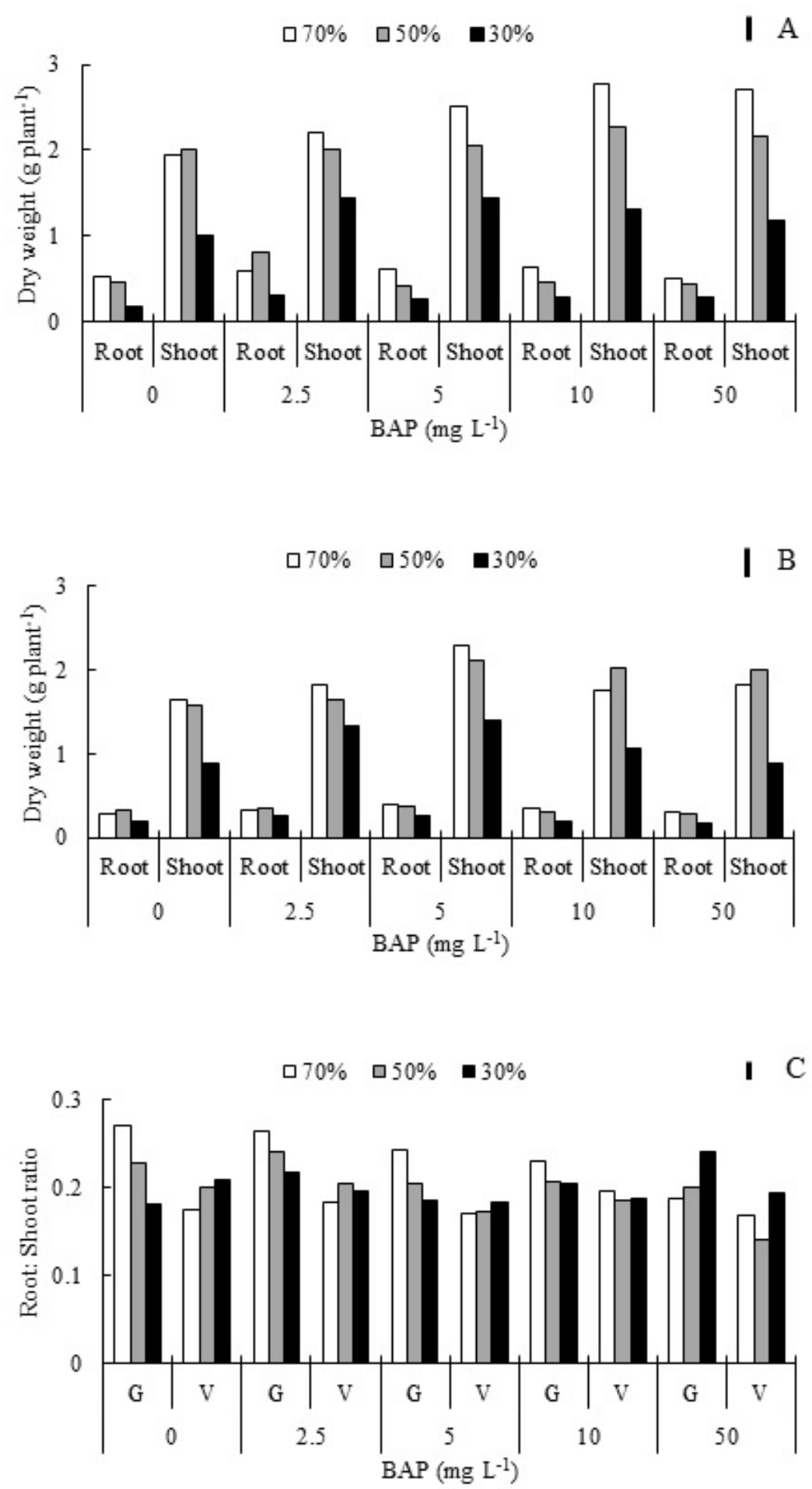

Figure 4. Total dry weight at the end of the 2014-2015 experiment in 'green' (A) and 'variegated' (B) Ficus benjamina plants grown under three light intensities: $70 \%, 50 \%$ and $30 \%$ full sunlight, sprayed with different BAP concentrations. Plate C indicates root: shoot ratio. Least significant differences (LSD) values were calculated. 
Individual leaf area at final harvest was not significantly different between green and variegated genotypes in BAPuntreated plants under either $70 \%$ or $50 \%$ full sun light intensity (Table 1). BAP sprays resulted in a generally significant leaf size increase in both genotypes under these light intensities. On the other hand, at 30\% full sun light intensity, untreated green plants developed significantly larger leaves than variegated ones. However, BAP sprays were more effective in promoting leaf size in variegated plants than in green ones, resulting in leaves from 10 or 50 $\mathrm{mg} \mathrm{L}^{-1} \mathrm{BAP}$-sprayed variegated plants bearing not smaller leaves than their green counter parts. Leaves from green and variegated plants at final harvest had similar specific leaf area (SLA) values, irrespective of BAP treatment, when compared at $70 \%$ full sun irradiance. Shading tended to increase SLA more in variegated plants than in green ones, and at 30\% irradiance variegated plants attained about $10 \%$ higher SLA values than green ones. In general, specific leaf area of both green and variegated plants were rather unaffected by BAP. On the other hand, LWR of BAP-untreated variegated plants was substantially higher than LWR of green ones, irrespective of irradiance. This trend was maintained in most (but not all) cases of BAP treatment, which had little impact on this parameter values. Light intensity also appeared to have a low impact on LWR (Table 1).

Table 1. Individual leaf area, specific leaf area (SLA) and the leaf weight ratio (LWR) at the end of the experiment for plants of two ('green' and 'variegated') F. benjamina genotypes grown under three light intensities $(70 \%, 50 \%$ or $30 \%$ full light sun) and sprayed with different concentrations of BAP $\left(\mathrm{mg} \mathrm{L}^{-1}\right)(\mathrm{n}=3)$.

\begin{tabular}{|c|c|c|c|c|c|c|}
\hline \multirow[t]{2}{*}{$\begin{array}{c}\text { Light } \\
\text { intensity }\end{array}$} & \multicolumn{2}{|c|}{$\begin{array}{l}\text { Individual leaf area } \\
\qquad\left(\mathrm{cm}^{2} \text { leaf }^{-1}\right)\end{array}$} & \multicolumn{2}{|c|}{$\begin{array}{c}\text { SLA } \\
\left(\mathrm{cm}^{2} \mathrm{~g}^{-1}\right)\end{array}$} & \multicolumn{2}{|c|}{$\begin{array}{c}\text { LWR } \\
\left(\mathrm{g} \mathrm{cm}^{-2}\right)\end{array}$} \\
\hline & 'Green' & 'Variegated' & 'Green' & 'Variegated' & 'Green' & 'Variegated' \\
\hline \multicolumn{7}{|c|}{$70 \%$} \\
\hline 0 & $22.25 \mathrm{bA}$ & $22.44 \mathrm{bA}$ & $370.52 \mathrm{aA}$ & $335.88 \mathrm{~dB}$ & $0.506 \mathrm{~dB}$ & $0.576 \mathrm{bcA}$ \\
\hline 2.5 & $31.99 \mathrm{aA}$ & $28.78 \mathrm{aA}$ & $348.54 \mathrm{bA}$ & $333.38 \mathrm{~dB}$ & $0.546 \mathrm{bB}$ & $0.618 \mathrm{aA}$ \\
\hline 5 & $32.84 \mathrm{aA}$ & $26.59 \mathrm{abB}$ & $367.21 \mathrm{aB}$ & $396.07 \mathrm{aA}$ & $0.567 \mathrm{aA}$ & $0.555 \mathrm{cA}$ \\
\hline 10 & $32.49 \mathrm{aA}$ & $29.55 \mathrm{aA}$ & $370.98 \mathrm{aA}$ & $363.66 \mathrm{bA}$ & $0.564 \mathrm{aB}$ & $0.585 \mathrm{bA}$ \\
\hline 50 & $30.48 \mathrm{bA}$ & $22.46 \mathrm{bB}$ & $346.37 \mathrm{bA}$ & $346.89 \mathrm{cA}$ & $0.528 \mathrm{cB}$ & $0.580 \mathrm{bA}$ \\
\hline \multicolumn{7}{|c|}{$\mathbf{5 0 \%}$} \\
\hline 0 & $20.97 \mathrm{bA}$ & $21.35 \mathrm{ba}$ & $396.46 \mathrm{bB}$ & $421.42 \mathrm{bA}$ & $0.503 \mathrm{cB}$ & $0.543 \mathrm{bA}$ \\
\hline 2.5 & $25.39 \mathrm{abA}$ & $21.34 \mathrm{bb}$ & $421.59 \mathrm{aA}$ & $431.23 \mathrm{aA}$ & $0.484 \mathrm{~dB}$ & $0.555 \mathrm{bA}$ \\
\hline 5 & $24.44 \mathrm{abA}$ & $27.42 \mathrm{aA}$ & $424.03 \mathrm{aA}$ & $416.93 \mathrm{bA}$ & $0.514 \mathrm{bcB}$ & $0.569 \mathrm{bA}$ \\
\hline 10 & $27.25 \mathrm{aA}$ & $23.52 \mathrm{abB}$ & $390.40 \mathrm{bB}$ & $431.44 \mathrm{aA}$ & $0.551 \mathrm{aA}$ & $0.551 \mathrm{bA}$ \\
\hline 50 & $28.02 \mathrm{aA}$ & $25.51 \mathrm{abA}$ & $397.13 b B$ & $423.82 \mathrm{bA}$ & $0.526 \mathrm{bB}$ & $0.583 \mathrm{aA}$ \\
\hline \multicolumn{7}{|c|}{$30 \%$} \\
\hline 0 & $20.58 \mathrm{aA}$ & $15.54 \mathrm{cB}$ & $527.86 \mathrm{aB}$ & $568.20 \mathrm{aA}$ & $0.511 \mathrm{aB}$ & $0.573 \mathrm{aA}$ \\
\hline 2.5 & $22.51 \mathrm{aA}$ & $18.79 \mathrm{bcB}$ & $490.27 \mathrm{bB}$ & $534.29 \mathrm{cA}$ & $0.507 \mathrm{aA}$ & $0.518 \mathrm{cA}$ \\
\hline 5 & $21.09 \mathrm{aA}$ & $16.93 \mathrm{bcB}$ & $512.55 \mathrm{abB}$ & $577.59 \mathrm{aA}$ & $0.498 \mathrm{bA}$ & $0.509 \mathrm{cA}$ \\
\hline 10 & $20.21 \mathrm{aB}$ & $24.93 \mathrm{aA}$ & $538.41 \mathrm{aB}$ & $558.45 \mathrm{bA}$ & $0.486 \mathrm{cB}$ & $0.568 \mathrm{aA}$ \\
\hline 50 & $21.86 \mathrm{aA}$ & $21.51 \mathrm{abA}$ & $498.68 \mathrm{bB}$ & $524.33 \mathrm{cA}$ & $0.510 \mathrm{aB}$ & $0.555 \mathrm{bA}$ \\
\hline
\end{tabular}

Different lower-case letters indicated significant differences between BAP concentrations for each light intensity while capital letters indicated significant differences between genotypes for each light intensity or BAP treatment at $\mathrm{P}<0.05$ by Tukey's test. 
In untreated controls, mean area of individual leaves of green and variegated genotypes was similar when grown under higher light intensities, while variegated plants produced smaller leaves under $30 \%$ full sun. BAP sprays induced a general increase in individual leaf area of both genotypes, except for the green genotype under the lowest light intensity, in which differences among BAP treatments were not significant. Promotion of final leaf area by cytokinins is a well-known phenomenon that may rely on increases in both cell division and cell expansion (Kuluev et al., 2018). Exogenous supply of BAP (5 to $200 \mathrm{mg} \mathrm{L}^{-1}$ ) has also proven effective in leaf size increase $(22.65 \%-29.39 \%)$ in ornamental foliage plants such as Epipremnun aureum (Di Benedetto et al., 2013). Leaves are initiated into the shoot apical meristem (SAM) and it has been suggested that not only short-distance signals are involved in leaf formation, but also long-distance, hormonal ones (Conklin et al., 2019). One of the earliest markers for leaf initiation is the down-regulation of KNOX genes in initial cells. KNOX targets are modulated by the cytokinin: low gibberellins ratio, which might explain the leaf size increase in $F$. benjamina BAP-sprayed plants. BAP also promoted the rate of appearance of new leaves (RLA) in both genotypes under all light conditions (Table 1). Because in the present work we did not attempt to measure branching, the increases may be the consequence of decreased phyllochron, or increased branching, or both. The latter possibility seems more likely, since both an acceleration of the production of new leaves in the stem and the promotion of lateral bud development are well known cytokinin-mediated processes ( $\mathrm{Li}$ et al., 2018). The main functions of endogenous cytokinins are to control cell cycle and SAM growth (Brenner and Schmülling, 2015). At the early stages of leaf development, treatment of exogenous BAP accelerates division of mesophyll cells, whereas at the later stages of development, BAP treatment activates expansion of growing cells and those, which have just accomplished their growth. On the other hand, during leaf formation, cytokinins are required to drive the cell division cycle at a normal speed and to obtain the required number of cell divisions to reach a normal leaf size (Skalák et al., 2019). The increased leaf number together with larger leaf size in BAP-treated plants resulted in a promotion of RLAER of the whole in both genotypes, regardless of light intensity in agreement with previous reports from our laboratory in other ornamental foliage plants (Di Benedetto et al., 2013; 2015a,b; 2018; 2020a, b).
Shading determined, as expected, a decrease in growth and development of both genotypes, regardless of the application or not of exogenous BAP. Final leaf area tended to decrease from $70 \%$ to $30 \%$ full sun light intensity in both genotypes, but the effect was more pronounced in the variegated one, especially when comparing $50 \%$ and $30 \%$ irradiance treatments. The rate of leaf appearance was also affected, and again the variegated genotype was the most affected; i.e., when comparing $70 \%$ to $50 \%$ full sun light treatments, RLA of green genotype was almost unaffected while a substantial decrease took place in the variegated genotype. The decrease in RLA with shading has also been reported for other species (Di Benedetto et al., 2013).

In the absence of BAP application, variegated plants achieved either similar or somewhat lower rates of leaf appearance than green ones (Table 2). BAP sprays promoted RLA in both genotypes, but specially in variegated plants, resulting in some cases in higher leaf appearance rates than in green ones (i.e., in plants sprayed with 2.5 or $5 \mathrm{mg} \mathrm{L}^{-1}$ BAP under $70 \%$ full sun intensity).

The RLAER of untreated plants did not differ significantly between genotypes. BAP sprays resulted, in general, in a significant promotion of RLAER values. Under the highest light intensity, green plants responded to increasing BAP concentrations, while maximum promotion in variegated plants was achieved with the lowest BAP concentration. At 30\% full sun light intensity RLAER values were low, and low BAP concentrations tended to achieve the maximum response, irrespective of genotype (Table 2).

In the absence of cytokinin application, variegated plants grew at a slower rate (i.e., lower RGR) than green ones (Table 2), resulting in smaller plants when compared at equal times (Figures 1-4). Differences in NAR between genotypes were larger than differences in RGR, which was compensated by LAR being generally higher in variegated plants than in green ones (Table 2). In agreement with this, the root: shoot ratios of green Ficus were generally higher than those of variegated plants (except for the lowest light intensity in Experiment 2 , in which no significant differences between genotypes were observed). Differences in LAR values between variegated and green genotypes are consistent with data previously reported for oleander (Nerium oleander L.) and willow myrtle (Agonis flexuosa) (Downton and Grant, 1994). 
Table 2. The rate of leaf appearance (RLA) and the relative leaf area expansion rate (RLAER) for plants of two ('green' and 'variegated') F. benjamina genotypes grown under three light intensities ( $70 \%, 50 \%$ or $30 \%$ full light sun) and sprayed with different concentrations of BAP $\left(\mathrm{mg} \mathrm{L}^{-1}\right)(\mathrm{n}=3) \pm \mathrm{SE}$.

\begin{tabular}{|c|c|c|c|c|}
\hline \multirow[t]{2}{*}{ Light intensity } & \multicolumn{2}{|c|}{ RLA (leaves week ${ }^{-1}$ ) } & \multicolumn{2}{|c|}{$\operatorname{RLAER}\left(\mathrm{cm}^{2} \mathrm{~cm}^{-2}\right.$ day $\left.^{-1}\right)$} \\
\hline & 'Green' & 'Variegated' & 'Green' & 'Variegated' \\
\hline \multicolumn{5}{|c|}{$70 \%$} \\
\hline 0 & $0.920 \mathrm{cA}$ & $0.911 \mathrm{bA}$ & $0.0155 \mathrm{cA}$ & $0.0169 \mathrm{cA}$ \\
\hline 2.5 & $0.973 \mathrm{bB}$ & $1.403 \mathrm{aA}$ & $0.0178 \mathrm{bB}$ & $0.0210 \mathrm{aA}$ \\
\hline 5 & $0.967 \mathrm{bcB}$ & $1.255 \mathrm{abA}$ & $0.0185 \mathrm{bB}$ & $0.0203 \mathrm{aA}$ \\
\hline 10 & $1.007 \mathrm{bcA}$ & $1.119 \mathrm{abA}$ & $0.0186 \mathrm{bA}$ & $0.0163 \mathrm{bA}$ \\
\hline 50 & $1.219 \mathrm{aA}$ & $1.277 \mathrm{abA}$ & $0.0200 \mathrm{aA}$ & $0.0174 \mathrm{bB}$ \\
\hline \multicolumn{5}{|c|}{$50 \%$} \\
\hline 0 & $0.750 \mathrm{bA}$ & $0.602 \mathrm{bB}$ & $0.0130 \mathrm{bA}$ & $0.0078 \mathrm{cB}$ \\
\hline 2.5 & $1.207 \mathrm{aA}$ & $0.864 \mathrm{abB}$ & $0.0152 \mathrm{aA}$ & $0.0124 \mathrm{aB}$ \\
\hline 5 & $1.082 \mathrm{aA}$ & $0.902 \mathrm{aA}$ & $0.0152 \mathrm{aA}$ & $0.0115 \mathrm{bB}$ \\
\hline 10 & $1.038 \mathrm{aA}$ & $0.894 \mathrm{aA}$ & $0.0152 \mathrm{aA}$ & $0.0113 \mathrm{bB}$ \\
\hline 50 & $1.007 \mathrm{aA}$ & $0.887 \mathrm{aA}$ & $0.0147 \mathrm{aA}$ & $0.0112 \mathrm{bB}$ \\
\hline \multicolumn{5}{|c|}{$30 \%$} \\
\hline 0 & $0.536 \mathrm{cA}$ & $0.491 \mathrm{bA}$ & $0.0076 \mathrm{dA}$ & $0.0078 \mathrm{dA}$ \\
\hline 2.5 & $0.738 \mathrm{abA}$ & $0.769 \mathrm{aA}$ & $0.0104 \mathrm{aA}$ & $0.0085 \mathrm{cA}$ \\
\hline 5 & $0.771 \mathrm{aA}$ & $0.775 \mathrm{aA}$ & $0.0095 \mathrm{bA}$ & $0.0102 \mathrm{aA}$ \\
\hline 10 & $0.788 \mathrm{aA}$ & $0.643 \mathrm{abB}$ & $0.0088 \mathrm{cA}$ & $0.0087 \mathrm{cA}$ \\
\hline 50 & $0.604 \mathrm{bcA}$ & $0.595 \mathrm{abA}$ & $0.0088 \mathrm{cA}$ & $0.0094 \mathrm{bA}$ \\
\hline
\end{tabular}

Different lower-case letters indicated significant differences between BAP concentrations for each light intensity while capital letters indicated significant differences between genotypes for each light intensity or BAP treatment at $\mathrm{P}<0.05$ by Tukey's test. The probability of the slope being zero was $\mathrm{P}$ $\leq 0.001$ for RLAER.

The analysis of data from the second experiment is presented in Table 3. In the absence of BAP application, green plants had significantly higher RGR than variegated ones under either $70 \%$ or $50 \%$ full sunlight. This was the consequence of higher NAR green vs variegated values, and despite LAR values varying in contrary sense (particularly under the highest irradiance). At 30\% full sun irradiance, low RGR values were observed for both genotypes, and differences between them were not significant. Under this low irradiance, green plants had significantly higher NAR values than variegated ones, but lower LAR, ultimately resulting in similar RGR values, compensated this. 
Table 3. Mean RGR, NAR and LAR values for plants of two ('green' and 'variegated') F. benjamina genotypes grown under three light intensities $\left(70 \%, 50 \%\right.$ or $30 \%$ full light sun) and sprayed with different concentrations of BAP (mg L - $\left.^{-1}\right)$ $(n=3)$. Different lower-case letters indicated significant differences between BAP concentrations for each light intensity while capital letters indicated significant differences between genotypes for each light intensity or BAP treatment at $\mathrm{P}<$ 0.05 by Tukey’s test.

\begin{tabular}{|c|c|c|c|c|c|c|}
\hline \multirow[t]{2}{*}{ Light intensity } & \multicolumn{2}{|c|}{$\operatorname{RGR}\left(\mathrm{g} \mathrm{g}^{-1}\right.$ day $\left.^{-1}\right)$} & \multicolumn{2}{|c|}{$\begin{array}{c}\text { NAR }\left(\mathrm{g} \mathrm{cm}^{-2} \mathrm{day}^{-1}\right) \\
\left(\mathbf{x} 10^{-5}\right)\end{array}$} & \multicolumn{2}{|c|}{$\operatorname{LAR}\left(\mathrm{cm}^{2} \mathrm{~g}^{-1}\right)$} \\
\hline & 'Green' & 'Variegated' & 'Green' & 'Variegated' & 'Green' & 'Variegated' \\
\hline \multicolumn{7}{|c|}{$70 \%$} \\
\hline 0 & $0.0160 \mathrm{cA}$ & $0.0146 \mathrm{cB}$ & $6.71 \mathrm{cA}$ & $5.26 \mathrm{~dB}$ & $238.45 \mathrm{cB}$ & $277.57 \mathrm{dA}$ \\
\hline 2.5 & $0.0178 \mathrm{bA}$ & $0.0194 \mathrm{aA}$ & $7.08 \mathrm{bA}$ & $6.01 \mathrm{bB}$ & $251.41 \mathrm{bB}$ & $322.80 \mathrm{bA}$ \\
\hline 5 & $0.0172 \mathrm{bA}$ & $0.0184 \mathrm{aA}$ & $6.74 \mathrm{cA}$ & $6.21 \mathrm{aA}$ & $255.19 \mathrm{bB}$ & $296.30 \mathrm{cA}$ \\
\hline 10 & $0.0190 \mathrm{aA}$ & $0.0190 \mathrm{aA}$ & $6.98 \mathrm{bcA}$ & $5.39 \mathrm{cdB}$ & $272.21 \mathrm{aB}$ & $352.50 \mathrm{aA}$ \\
\hline 50 & $0.0193 \mathrm{aA}$ & $0.0169 \mathrm{bA}$ & $7.71 \mathrm{aA}$ & $5.31 \mathrm{~dB}$ & $250.32 \mathrm{bB}$ & $318.27 \mathrm{bA}$ \\
\hline \multicolumn{7}{|c|}{$50 \%$} \\
\hline 0 & $0.0137 \mathrm{bA}$ & $0.0097 \mathrm{bcB}$ & $6.27 \mathrm{cA}$ & $4.37 \mathrm{~dB}$ & $218.50 \mathrm{aA}$ & $221.97 \mathrm{aA}$ \\
\hline 2.5 & $0.0163 \mathrm{aA}$ & $0.0129 \mathrm{aB}$ & $7.41 \mathrm{aA}$ & $5.70 \mathrm{aB}$ & $219.97 \mathrm{aA}$ & $226.32 \mathrm{aA}$ \\
\hline 5 & $0.0158 \mathrm{aA}$ & $0.0122 \mathrm{aB}$ & $7.06 \mathrm{bA}$ & $5.47 \mathrm{bB}$ & $223.80 \mathrm{aA}$ & $223.03 \mathrm{aA}$ \\
\hline 10 & $0.0162 \mathrm{aA}$ & $0.0105 \mathrm{bB}$ & $7.40 \mathrm{aA}$ & $4.74 \mathrm{cB}$ & $218.92 \mathrm{aA}$ & $221.52 \mathrm{aA}$ \\
\hline 50 & $0.0154 \mathrm{abA}$ & $0.0091 \mathrm{cB}$ & $7.02 \mathrm{bA}$ & $3.95 \mathrm{eB}$ & $219.37 \mathrm{aB}$ & $230.38 \mathrm{aA}$ \\
\hline \multicolumn{7}{|c|}{$30 \%$} \\
\hline 0 & $0.0092 \mathrm{cA}$ & $0.0086 \mathrm{cA}$ & $4.74 \mathrm{dA}$ & $3.52 \mathrm{cB}$ & $194.09 \mathrm{cB}$ & $244.32 \mathrm{cA}$ \\
\hline 2.5 & $0.0141 \mathrm{aA}$ & $0.0131 \mathrm{aA}$ & $6.07 \mathrm{aA}$ & $4.77 \mathrm{aB}$ & $232.29 \mathrm{aB}$ & $274.63 \mathrm{aA}$ \\
\hline 5 & $0.0106 \mathrm{bA}$ & $0.0118 \mathrm{bA}$ & $5.13 \mathrm{bA}$ & $4.75 \mathrm{aA}$ & $206.63 \mathrm{bB}$ & $248.12 \mathrm{cA}$ \\
\hline 10 & $0.0102 \mathrm{bA}$ & $0.0118 \mathrm{bA}$ & $5.02 \mathrm{cA}$ & $4.47 \mathrm{bA}$ & $203.19 \mathrm{bB}$ & $263.98 \mathrm{abA}$ \\
\hline 50 & $0.0104 \mathrm{bA}$ & $0.0116 \mathrm{bA}$ & $5.14 \mathrm{bA}$ & $4.48 \mathrm{bA}$ & $202.33 \mathrm{bB}$ & $258.93 \mathrm{bA}$ \\
\hline
\end{tabular}

Different lower-case letters indicated significant differences between BAP concentrations for each light intensity while capital letters indicated significant differences between genotypes for each light intensity or BAP treatment at $\mathrm{P}<0.05$ by Tukey's test.

BAP applications, as a rule, tended to increase RGR and NAR values, but these effects varied in magnitude (and significance) among genotypes and irradiance levels. To analyse these differential responses, the effect of BAP treatment on RGR and its components, NAR and LAR, shown as a percentage of change over non-treated controls, is presented in Figure 5. BAP was generally more effective in promoting RGR in variegated than in green genotypes (the exceptions were $50 \mathrm{mg} \mathrm{L}^{-1}$ treatments under $70 \%$ and
$50 \%$ full sun, in which green plants RGR were slightly more promoted by BAP than variegated ones). In variegated plants, the maximum promotion of RGR was found at the lowest BAP concentration. Up to a high degree, BAP-driven promotion in RGR of variegated plants was paralleled by increases in NAR, while the effect on LAR was in most cases of a lower magnitude and less consistent; i.e., BAP promoted LAR of both genotypes under $70 \%$ and $30 \%$, but not under $50 \%$, full sun light intensity. 

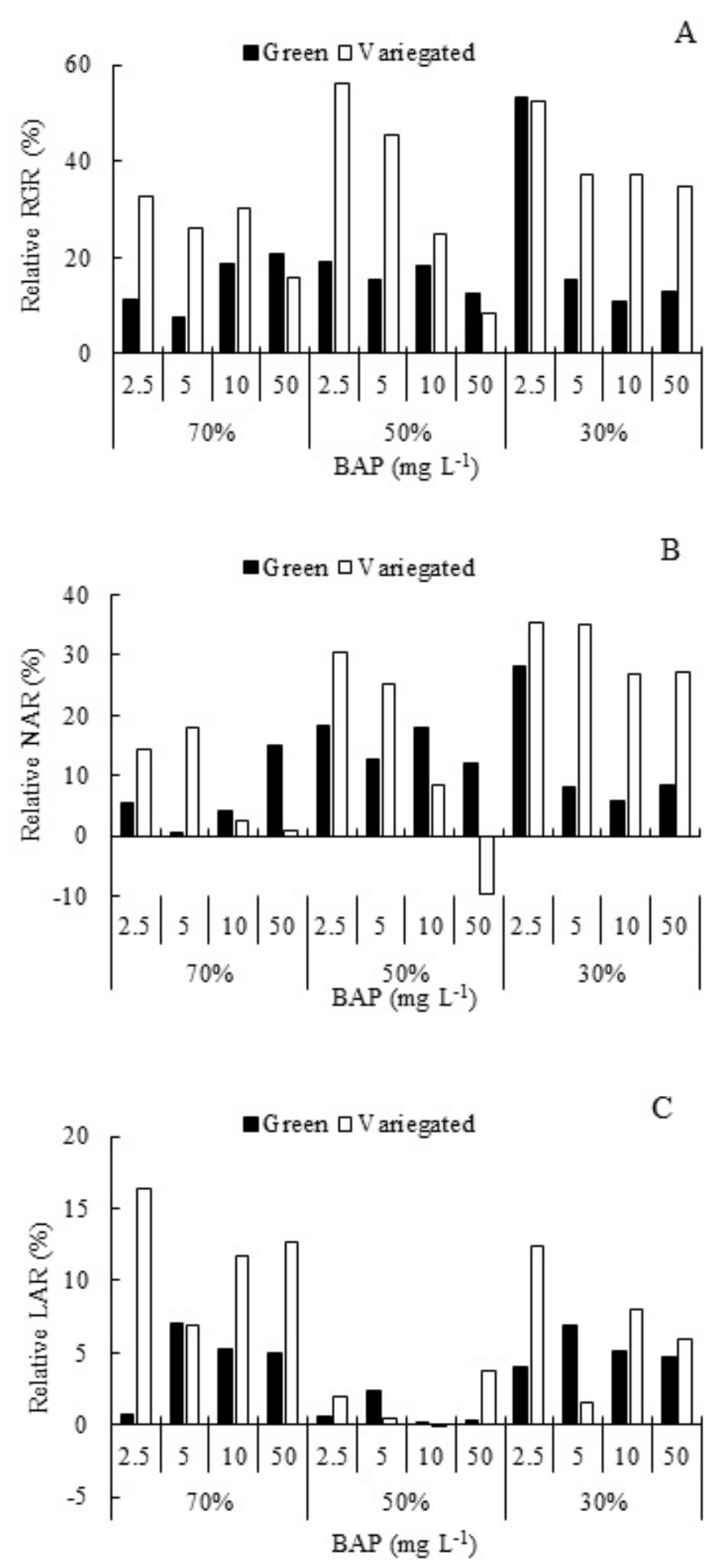

Figure 5. The effect of a 2.5, 5, 50 or $100 \mathrm{mg} \mathrm{L}^{-1}$ BAP spray application on relative RGR (A), relative NAR (B) and relative LAR (C) related to control 'green' and 'variegated' Ficus benjamina plants grown under three light intensities: $70 \%, 50 \%$ and $30 \%$ full sunlight. 
Post-transplant foliar applications of cytokinins have been shown to effectively promote shoot development and biomass accumulation in a number of ornamental plants grown in pots in several ornamental species such as Epipremnum aureum (Di Benedetto et al., 2013; 2015a, b), Monstera deliciosa (De Lojo and Di Benedetto, 2014) and Impatiens 'New Guinea' (Molinari et al., 2018, 2019), thus overcoming the root restriction syndrome. Root apexderived cytokinins have been associated with improved photosynthesis, in turn related with both increases in chlorophyll content and higher nitrogen partitioning to leaves, for a number of species (Cortleven and Schmülling, 2015; Gu et al., 2018). As expected, exogenous BAP application in general promoted growth and development of both Ficus genotypes. This promotion appeared to be stronger in variegated plants than in green ones, since variegated plants required either lower number of sprays (Experiment 1) or concentration (Experiment 2) to obtain similar promoting effects (Figure 5).

Decreasing irradiance from $70 \%$ to $50 \%$ full sun had a larger impact on RGR of variegated, rather than green, ecotypes (approximately $-15 \%$ vs. $-40 \%$, respectively), irrespective of BAP treatments. Decreasing irradiance from $50 \%$ to $30 \%$ full sun had a much larger negative impact on RGR of green genotype than in variegated plants. The low impact of decreasing irradiance from $50 \%$ to $30 \%$ full sun intensity in variegated plants RGR was attributable to high LAR values of plants developed under the lowest light intensity (Table 3).

The shoot DMC ranged between $19.4 \%$ and $23.7 \%$ and was unaffected by either type of Ficus genotype, BAP treatment or light intensity (Table 4). Total soluble carbohydrate concentration was either similar or higher in leaves from green plants than in variegated ones. Under either $70 \%$ or $50 \%$ full sun, BAP application in green plants at $5-50 \mathrm{mg} \mathrm{L}^{-1}$ significantly increased TSC over controls. A similar but less marked response was observed in variegated plants. On the other hand, no such promotion was observed under 30\% full sun light intensity (Table 4). There was also a trend to lower TSC values under the lowest light intensity.

Chlorophyll concentration per unit leaf area was, in almost all cases, significantly higher in leaves from the green genotype than in the variegated one (Table 5). In the green genotype, BAP application at any concentration and under any light intensity resulted in a significant increase in chlorophyll content. On the other hand, no such clear effect of BAP on chlorophyll content could be distinguished in the variegated genotype, although a trend to higher values in hormone-treated plants was observed under higher light intensities. Furthermore, in control plants of both green and variegated genotypes, chlorophyll concentration per unit leaf area tended to increase at lower light intensities, while in BAP-treated plants this trend was less marked (Table 5).

Total $\mathrm{N}$ concentration per unit dry weight was constant across genotypes, BAP treatments and light intensities. Nevertheless, in some cases under $70 \%$ and $50 \%$ full sun light intensity, green plants achieved significantly higher values than variegated ones (Table 5). Also, in many cases BAP treatment slightly but significantly increased $\mathrm{N}$ concentration over untreated controls, as seen for green plants under every light intensity, or in variegated plants under $30 \%$ full sun irradiance (Table 5). It is known that total leaf $\mathrm{N}$ is directly associated with the photosynthetic rate, with around $50 \%$ of leaf nitrogen taking part of the Rubisco enzyme (Evans and Clarke, 2019). 
Table 4. Shoot dry matter content (DMC) and total soluble carbohydrates (TSC) at the end of the experiment for plants of two ('green' and 'variegated') F. benjamina genotypes grown under three light intensities (70\%, 50\% or 30\% full sun light) and sprayed with BAP at different concentrations $\left(\mathrm{mg} \mathrm{L}^{-1}\right)(\mathrm{n}=3)$.

\begin{tabular}{|c|c|c|c|c|}
\hline \multirow[t]{2}{*}{ Lightintensity } & \multicolumn{2}{|c|}{ DMC(\%) } & \multicolumn{2}{|c|}{ TSC (mg g g dry weight) } \\
\hline & 'Green' & 'Variegated' & 'Green' & 'Variegated' \\
\hline \multicolumn{5}{|c|}{$70 \%$} \\
\hline 0 & $20.9 \mathrm{aA}$ & $19.4 \mathrm{aA}$ & $3.94 \mathrm{cA}$ & $3.41 \mathrm{bB}$ \\
\hline 2.5 & $21.7 \mathrm{aA}$ & $21.1 \mathrm{aA}$ & $3.75 \mathrm{cA}$ & $3.12 \mathrm{cB}$ \\
\hline 5 & $21.1 \mathrm{aA}$ & $21.2 \mathrm{aA}$ & $4.28 \mathrm{bA}$ & $4.42 \mathrm{aA}$ \\
\hline 10 & $21.9 \mathrm{aA}$ & $20.9 \mathrm{aA}$ & $5.43 \mathrm{aA}$ & $3.68 \mathrm{bB}$ \\
\hline 50 & $22.5 \mathrm{aA}$ & $23.9 \mathrm{aA}$ & $4.85 \mathrm{bA}$ & $4.63 \mathrm{aA}$ \\
\hline \multicolumn{5}{|c|}{$50 \%$} \\
\hline 0 & $21.1 \mathrm{aA}$ & $20.5 \mathrm{aA}$ & $3.44 \mathrm{bA}$ & $3.59 \mathrm{bA}$ \\
\hline 2.5 & $21.9 \mathrm{aA}$ & $20.6 \mathrm{aA}$ & $2.71 \mathrm{cA}$ & $2.85 \mathrm{cA}$ \\
\hline 5 & $20.6 \mathrm{aA}$ & $20.8 \mathrm{aA}$ & $4.29 \mathrm{aA}$ & $3.42 \mathrm{bB}$ \\
\hline 10 & $22.7 \mathrm{aA}$ & $20.7 \mathrm{aA}$ & $4.49 \mathrm{aA}$ & $3.69 \mathrm{aB}$ \\
\hline 50 & $22.1 \mathrm{aA}$ & $21.3 \mathrm{aA}$ & $4.29 \mathrm{aA}$ & $3.88 \mathrm{aB}$ \\
\hline \multicolumn{5}{|c|}{$30 \%$} \\
\hline 0 & $22.6 \mathrm{aA}$ & $23.7 \mathrm{aA}$ & $3.39 \mathrm{bA}$ & $3.44 \mathrm{aA}$ \\
\hline 2.5 & $21.2 \mathrm{aA}$ & $21.8 \mathrm{aA}$ & $3.91 \mathrm{aA}$ & $3.49 \mathrm{aB}$ \\
\hline 5 & $20.6 \mathrm{aA}$ & $20.5 \mathrm{aA}$ & $2.94 \mathrm{cA}$ & $2.65 \mathrm{cA}$ \\
\hline 10 & $19.7 \mathrm{aA}$ & $21.4 \mathrm{aA}$ & $3.42 \mathrm{bA}$ & $3.20 \mathrm{bA}$ \\
\hline 50 & $22.3 \mathrm{aA}$ & $23.4 \mathrm{aA}$ & $3.32 \mathrm{bA}$ & $3.43 \mathrm{aA}$ \\
\hline
\end{tabular}

Different lower-case letters indicated significant differences between BAP concentrations for each light intensity while capital letters indicated significant differences between genotypes for each light intensity or BAP treatment at $\mathrm{P}<0.05$ by Tukey's test. 
Table 5. Chlorophyll and nitrogen content at the end of the experiment for plants of two ('green' and 'variegated') $F$. benjamina genotypes grown under three light intensities $(70 \%, 50 \%$ or $30 \%$ full sun light) and sprayed with BAP at different concentrations $\left(\mathrm{mg} \mathrm{L}^{-1}\right)(\mathrm{n}=3)$.

\begin{tabular}{|c|c|c|c|c|}
\hline \multirow[t]{2}{*}{ Light intensity } & \multicolumn{2}{|c|}{ Chlorophyll (mg m²) } & \multicolumn{2}{|c|}{ N ( $\mathrm{g} \mathrm{g}^{-1}$ dry weight) } \\
\hline & 'Green' & 'Variegated' & 'Green' & 'Variegated' \\
\hline \multicolumn{5}{|c|}{$70 \%$} \\
\hline 0 & $417.02 \mathrm{cA}$ & $391.72 \mathrm{cB}$ & $32.51 \mathrm{bA}$ & $29.60 \mathrm{aB}$ \\
\hline 2.5 & $492.06 \mathrm{aA}$ & $434.11 \mathrm{bB}$ & $32.53 \mathrm{bA}$ & $32.01 \mathrm{aA}$ \\
\hline 5 & $467.04 \mathrm{bA}$ & $416.53 \mathrm{bB}$ & $32.98 \mathrm{bA}$ & $32.04 \mathrm{aA}$ \\
\hline 10 & $478.10 \mathrm{bA}$ & $399.30 \mathrm{cB}$ & $35.22 \mathrm{aA}$ & $26.55 \mathrm{bB}$ \\
\hline 50 & $456.77 \mathrm{bA}$ & $481.28 \mathrm{aA}$ & $33.00 \mathrm{bA}$ & $31.51 \mathrm{aA}$ \\
\hline \multicolumn{5}{|c|}{$50 \%$} \\
\hline 0 & $458.88 \mathrm{bA}$ & $405.85 \mathrm{cB}$ & $29.50 \mathrm{bA}$ & $31.50 \mathrm{aA}$ \\
\hline 2.5 & $519.70 \mathrm{aA}$ & $492.36 \mathrm{aB}$ & $33.01 \mathrm{aA}$ & $31.04 \mathrm{aA}$ \\
\hline 5 & $537.61 \mathrm{aA}$ & $439.63 \mathrm{bB}$ & $32.53 \mathrm{aA}$ & $27.00 \mathrm{bB}$ \\
\hline 10 & $528.39 \mathrm{aA}$ & $429.29 \mathrm{bB}$ & $33.04 \mathrm{aA}$ & $31.01 \mathrm{aA}$ \\
\hline 50 & $506.27 \mathrm{aA}$ & $451.69 \mathrm{aB}$ & $33.00 \mathrm{aA}$ & $28.00 \mathrm{bB}$ \\
\hline \multicolumn{5}{|c|}{$30 \%$} \\
\hline 0 & $475.73 \mathrm{cA}$ & $481.32 \mathrm{aA}$ & $29.80 \mathrm{bA}$ & $28.01 \mathrm{bA}$ \\
\hline 2.5 & $545.77 \mathrm{aA}$ & $435.86 \mathrm{bB}$ & $31.01 \mathrm{aA}$ & $28.53 \mathrm{bA}$ \\
\hline 5 & $574.47 \mathrm{aA}$ & $447.21 \mathrm{aB}$ & $28.97 \mathrm{bA}$ & $31.00 \mathrm{aA}$ \\
\hline 10 & $499.69 \mathrm{bA}$ & $448.24 \mathrm{aB}$ & $29.44 \mathrm{bA}$ & $31.49 \mathrm{aA}$ \\
\hline 50 & $496.80 \mathrm{bA}$ & $450.31 \mathrm{aB}$ & $28.96 \mathrm{bA}$ & $32.00 \mathrm{aA}$ \\
\hline
\end{tabular}

Different lower-case letters indicated significant differences between BAP concentrations for each light intensity while capital letters indicated significant differences between genotypes for each light intensity or BAP treatment at $\mathrm{P}<0.05$ by Tukey's test.

To assess the impact of variation in NAR and LAR on RGR, linear regression analyses on data from the different BAP treatments and light environments were performed for each genotype. A close direct relationship between NAR and RGR was found for both genotypes $\left(\mathrm{r}^{2}=0.885\right.$ and $0.766, p<0.01$, for green and variegated plants, respectively; Figure 6A). In addition, a significant direct relationship between RGR and LAR was observed for both genotypes, although this relationship was somewhat less strong than the former $\left(\mathrm{r}^{2}=0.775\right.$ and $0.709, p<0.001$, for green and variegated plants, respectively) (Figure 6B). 


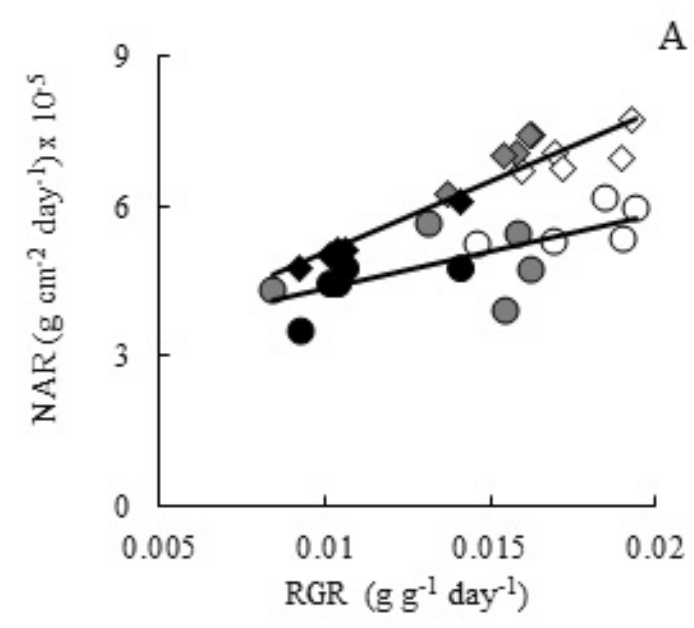

A

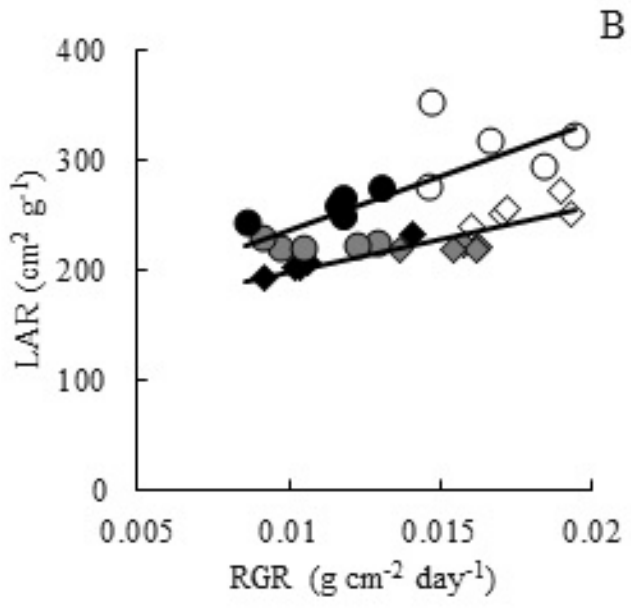

Figure 6. Relationships between the net assimilation rates (NAR) (A) and the relation of leaf area (LAR) (B) and the relative growth rate (RGR) in 'green' $(\diamond)$ or 'variegated' $(\circ)$ Ficus benjamina L. genotypes. Linear regression equations are $\mathrm{NAR}_{\text {GREN }}=285.97 \mathrm{RGR}+2.23\left(\mathrm{r}^{2}=0.885, \mathrm{P}<0.001\right) ; \mathrm{NAR}_{\mathrm{VARIEGATED}}=162.75 \mathrm{RGR}+2.57\left(\mathrm{r}^{2}=0.491 ; \mathrm{P}<\right.$ $0.001) ; \mathrm{LAR}_{\text {GREEN }}=5,275.70 \mathrm{RGR}+152.65\left(\mathrm{r}^{2}=0.734 ; \mathrm{P}<0.001\right) ;$ LAR $_{\text {VARIEGATED }}=9,909.90 \mathrm{RGR}+136.57\left(\mathrm{r}^{2}=\right.$ $0.596 ; \mathrm{P}<0.001$ ). Symbols indicate $70 \%$ (white), $50 \%$ (grey) and 30\% (black) full sunlight.

Leaf nitrogen and carbohydrate contents were closely associated in both genotypes, as revealed by regression analysis $\left(\mathrm{r}^{2}=0.870\right.$ and $0.458, p<0.001$, data not shown) for green and variegated plants, respectively. These relationships appeared to be very similar for both genotypes, being differences in equation parameters not significant. Thus in fact the relationship between both variables including data from both genotypes could be described by a single equation $\left(r^{2}=0.715, p<0.001\right)$ (Figure 7).

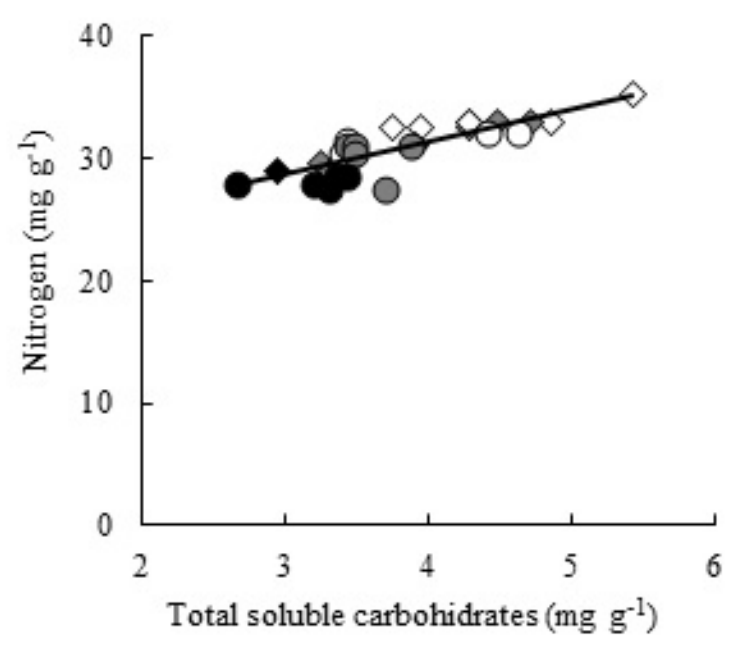

Figure 7. Relationships between the nitrogen content and total soluble carbohydrates (TSC) in 'green' $(\diamond)$ or 'variegated' ( $\mathrm{O}$ ) Ficus benjamina L. genotypes grown under three light integrals and sprayed with different BAP concentrations. Linear regression equations are $\mathrm{N}_{\mathrm{N}}=2.69 \mathrm{TSC}+20.60\left(\mathrm{r}^{2}=0.715 ; \mathrm{P}<0.001\right)$. Symbols indicate $70 \%$ (white), $50 \%$ (grey) and $30 \%$ (black) full sunlight. 
The RGR promotion in BAP treated Ficus (either green or variegated) was mainly the consequence of increases in NAR rather than LAR, as evidenced in Figure 6. This somewhat differs with the results obtained in Epipremnum aureum, in which BAP promoted RGR solely because of much increased NAR, while LAR was inversely, albeit slightly, related to RGR. It is well known that cytokinins exert an effect on photo assimilates partitioning, through which growth of the aerial part is promoted at the expense of the root system. However, in E. aureum this effect was shown not to result in an increased LAR, but instead in thicker stems, petioles and leaves, which in turn resulted in lower SLA values than in untreated controls (Di Benedetto et al., 2015b). In the present work, however, both LAR components, i.e. SLA and LWR, were scarcely affected by BAP treatment. To explain the difference between pothos and Ficus regarding BAP effect on SLA, it may be hypothesized that in the case of Ficus, any BAP driven leaf thickening may be counteracted by the fact that recently unfolded leaves (whose production is strongly promoted by BAP) are very thin and display consequently high SLA values (data not shown). On the other hand, our finding that BAP promotes growth by increasing NAR rather than LAR, in in agreement with Veneklaas et al. (2002) who found that the inherently low RGR values of F. benjamina, in comparison with herbaceous plants, was attributable to low LAR and SLA, but not NAR, values.

Shading from high to moderate light intensity $(70 \%$ to $50 \%$ full sun) led to a decreased growth rate especially in the variegated genotype, and this effect was associated with a decrease in NAR, which was virtually unaffected in green plants. Conversely, shading from moderate to low light intensity ( $50 \%$ to $30 \%$ full sun) had a stronger effect on growth and assimilation rates in the green genotype than in the variegated one (i.e., RGR and NAR decreased by $29.8 \%$ and $25.8 \%$ in green plants averaging all BAP treatments, while in variegated plants only about $8 \%$ decrease was found for both variables). The fact that a moderate shading had a more negative effect on variegated plants suggests that these plants may be adapted to higher light intensities, as suggested by Klancnic et al. (2016).

In sum, our results are consistent with the proposed hypothesis, namely, that variegation imposes a limitation to photosynthesis that is compensated for by an increased photo assimilate partitioning towards the aerial part, leading to higher LAR and lower root:shoot ratios in variegated plants than in their green counterparts. This limitation in turn makes plants more prone to suffering from shading, and more responsive to factors that may improve photosynthesis, such as cytokinin levels. The quantitative differences found in this work between the green and the variegated genotypes could be associated with different cytokinin leaf content between them in agreement with Van Staden et al. (1994) findings in Schefflera arboricola. The highest concentration tested $\left(50 \mathrm{mg} \mathrm{L}^{-1}\right)$ was the most effective only in the green genotype under the highest daily light irradiance. In all other cases, a low BAP dose was enough to promote a high response. This suggests that BAP may turn supra optimal in plants that cannot express a high photosynthetic potential due either to low irradiance or the presence of yellow areas in leaves.

Variegated $F$. benjamina cultivars are popular for cultivation especially at indoor locations due to their ornamental value; however, implications of leaf variegation on growth and development of these cultivars, as compared with green cultivars, are still poorly understood. The analysis of the costs and benefits of leaf variegation has been addressed lately in a series of studies (Wang et al., 2016). In several cases, it has been demonstrated that variegation does not represent a significant cost because of improved light transmission to inner zone of canopies, or even may help plants cope with abiotic stress (Chen et al., 2017). Nevertheless, the presence of important leaf zones almost totally devoid of chlorophyll in variegated plants such as Ficus may lower overall growth, in comparison to totally green genotypes, as shown for oleander (Nerium oleander L.) and willow myrtle (Agonis flexuosa) by Downton and Grant (1994). The impact of a reduced photosynthetic area in these plants may be compensated, up to some extent, by an increased partitioning towards leaf area development resulting in higher LAR (Downton and Grant, 1994). Furthermore, it could be expected that factors that improve carbon fixation per unit leaf area may benefit more variegated plants than green ones, and conversely, conditions that impair photosynthesis may be more detrimental, in variegated plants than in green ones (Zhang et al., 2018). In this work, we show that this indeed is the case in F. balsamina, in which foliar application of a photosynthesis-promoting cytokinin resulted in a higher growth promotion in variegated than in green genotypes, while the opposite resulted from shading plants.

Improving biomass accumulation is very important in ornamental plants with inherent low RGR such as $F$. benjamina, in which fast-growing clone selection programs have given limited results (Veneklaas et al., 2002). From the grower point of view, the exogenous applications of cytokinins may represent a tool for improving crop productivity in Benjamin fig plants, especially when the volume available for root growth is low, while optimum application doses to apply may depend on light intensity and genotype.

\section{Author Contribution}

$\mathrm{ADB}^{0000-0001-7346-5616}$ provided the structure and conditions to develop the experiments and conducted its. ADB, CG 0000-0002-7958${ }^{0110}$, and $\mathrm{JT}^{0000-0002-0041-7274}$ wrote the manuscript, carried out the statistical analysis and contributed to the discussion of results. All the authors read and approved the final version of the paper.

\section{Acknowledgements}

This work was supported by the University of Buenos Aires Science Program 2014-2017 (Grant No Q322). 


\section{References}

BRENNER, W.G.; SCHMÜLLING, T. Summarizing and exploring data of a decade of cytokinin-related transcriptomics. Frontiers in Plant Science, v.17, n.6, p.29, 2015. https://doi.org/10.3389/fpls.2015.00029

CHEN, Y.S.; CHESSON, P.; WU, H.W.; PAO, SH.; LIU, J.W.; CHIEN, L.F.; YONG, J.W.H.; SHEUE, C.R. Leaf structure affects a plant's appearance: combined multiple-mechanisms intensify remarkable foliar variegation. Journal of Plant Research, v.130, n.2, p.311325, 2017. https://doi.org/10.1007/s10265-016-0890-4

CONKLIN, P.A.; STRABLE, J.; LI, S.; SCANLON, M.J. On the mechanisms of development in monocot and eudicot leaves. New Phytologist, v.221, n.2, p.706-724, 2019. https://doi.org/10.1111/nph.15371

CORTLEVEN, A.; SCHMÜLLING, T. Regulation of chloroplast development and function by cytokinin. Journal of Experimental Botany, v.66, n.16, p.4999-5013, 2015. https://doi.org/10.1093/jxb/erv132

DAVIÈRE, J.M.; ACHARD, P. Organ communication: Cytokinins on the move. Nature Plants, v.3, n.8, p.1-2, 2017. https://doi.org/10.1038/nplants.2017.116.

DE LOJO, J.; DI BENEDETTO, A. Biomass accumulation and leaf shape can be modulated by an exogenous spray of 6-benzylaminopurine in the ornamental foliage plant Monstera deliciosa (Liebm.). The Journal of Horticultural Science and Biotechnology, v.89, n.2, p.136-140, 2014. https://doi.org/10.1080/14620316.2014.11513059

DI BENEDETTO A; RATTIN, J; TOGNETTI, J.; CARNELOS, D.; LOZANO-MIGLIOLI, J.; GIARDINA, E.; ARAKI, A.; CORO, M.; PICO-ESTRADA, O.; TERUEL, J.; DI MATTEO, J.; GERASI, J.; BARRERA, L.; ALONSO, E.; GRIGOLI, L. Technological Uses of Exogenous Cytokinins in Vegetables. In: KORTESMÄKI, S. Cytokinins: Biosynthesis and Uses. Nova Science Publishers, New York, 2020b. pp. 107-155

DI BENEDETTO, A.; GALMARINI, C.; TOGNETTI, J. Contribution of changes in leaf size and leaf production rate to cytokinin mediated growth promotion in Epipremnum aureum L. The Journal of Horticultural Science \& Biotechnology, v.88, p.179-186, 2013.

DI BENEDETTO, A.; GALMARINI, C.; TOGNETTI, J. Effects of combined or single exogenous auxin and/or cytokinin applications on growth and leaf area development in Epipremnum aureum. The Journal of Horticultural Science and Biotechnology, v.90, n.6, p.643-654, 2015 b. https://doi.org/10.1080/14620316.2015.11668727
DI BENEDETTO, A.; GALMARINI, C.; TOGNETTI, J. Exogenous cytokinin promotes Epipremnum aureum L. growth through enhanced dry weight assimilation rather than through changes in partitioning. American Journal of Experimental Agriculture, v.5, p.419-434, 2015a. https://doi.org/10.9734/AJEA/2015/13398

DI BENEDETTO, A.; GALMARINI, C.; TOGNETTI, J. New insight into how thigmomorphogenesis affects Epipremnum aureum L.: Interactions between vine training system and exogenous auxin and cytokinin action in plant development. Horticultura Brasileira, v.36, n.3, p.330340, 2018. http://dx.doi.org/10.1590/S0102-053620180308

DI BENEDETTO, A.; GIARDINA, E.; DE LOJO, J.; GANDOLFO, E.; HAKIM, G. Exogenous benzyl amino purine (BAP) applications for the ornamental pot industry. In: KORTESMÄKI, S. Cytokinins: Biosynthesis and Uses. Nova Science Publishers, New York, 2020a. pp.1-56.

DI BENEDETTO, A.; KLASMAN, R. River waste as a potentially amendment for low quality Sphagnum peat. European Journal of Horticultural Science, v.72, n.6, p.260, 2007.

DI BenedetTo, A.; TOGNETTI, J. Técnicas de análisis de crecimiento de plantas: su aplicación a cultivos intensivos. RIA. Revista de Investigaciones Agropecuarias, v.42, n.3, p.258-282, 2016. http://www. redalyc.org/articulo.oa?id=86449712008

DI BENEDETTO, A.; TOGNETTI, J.; GALMARINI, C. Biomass production in ornamental foliage plants: Crop productivity and mechanisms associated to exogenous cytokinin supply. The Americas Journal of Plant Science \& Biotechnology, v.4, n.1, p.1-22, 2010.

DOWNTON, W.J.S.; GRANT, W.J.R. Photosynthetic and growth responses of variegated ornamental species to elevated $\mathrm{CO}_{2}$. Functional Plant Biology, v.21, n.3, p.273279, 1994. https://doi.org/10.1071/PP9940273

DURÁN-MEDINA, Y., DÍAZ-RAMÍREZ, D.; MARSCHMARTÍNEZ, N. Cytokinins on the Move. Frontiers in Plant Science, v.8, p.146, 2017. https://doi.org/10.3389/ fpls.2017.00146

EVANS, J.R., CLARKE, V.C. The nitrogen cost of photosynthesis. Journal of Experimental Botany, v.70, n.1, p.7-15, 2019.

GU, J.; LI, Z.; MAO, Y.; STRUIK, P.C.; ZHANG, H.; LIU, L.; WANG, Z.; YANG, J. Roles of nitrogen and cytokinin signals in root and shoot communications in maximizing of plant productivity and their agronomic applications. Plant Science, v.274, p.320-331, 2018. https://doi.org/10.1016/j. plantsci.2018.06.010 
KLANČNIK, K.; LEVPUŠČEK, M.; GABERŠČIK, A. Variegation and red abaxial epidermis define the leaf optical properties of Cyclamen purpurascens. Flora, v.224, p.87-95, 2016. https://doi.org/10.1016/j.flora.2016.07.010

KONOPLYOVA, A.; PETROPOULOU, Y.; YIOTIS, C.; PSARAS, G.K.; MANETAS, Y. The fine structure and photosynthetic cost of structural leaf variegation. FloraMorphology, Distribution, Functional Ecology of Plants, v.203, n.8, p.653-662, 2008. https://doi.org/10.1016/j. flora.2007.10.007

KULUEV, B.; AVALBAEV, A.; NIKONOROV, Y.; ERMOSHIN, A.; YULDASHEV, R.; AKHIAROVA, G.; SHAKIROVA, F.; CHEMERIS, A. Effect of constitutive expression of Arabidopsis CLAVATA3 on cell growth and possible role of cytokinins in leaf size control in transgenic tobacco plants. Journal of Plant Physiology, v.231, p.244250, 2018. https://doi.org/ 10.1016/j.jplph.2018.09.011

LI, G.; TAN, M.; CHENG, F.; LIU, X.; QI, S.; CHEN, H.; ZHANG, D.; ZHAO, C.; HAN, M.; MA, J. 2018. Molecular role of cytokinin in bud activation and outgrowth in apple branching based on transcriptomic analysis. Plant Molecular Biology, v.98, n.3, p.261-274, 2018. https://doi. org/10.1007/s1110 3-018-0781-2

MOLINARI, J.; FUJINUMA, P.; PAGANI, A.; BUYATTI, M.; GIARDINA, E.; DI BENEDETTO, A. New Guinea Impatiens (Impatiens hawkeri Bull) hormonal effects on the post-transplant biomass accumulation. Journal of Advances in Agriculture, v.10, p.1629-1649, 2019.

MOLINARI, J.; PAGANI, A.; BUYATTI, M.; GIARDINA, E.; DI BENEDETTO, A. 2018. Impatiens 'New Guinea' (Impatiens hawkeri Bull) propagation effects on the pretransplant biomass accumulation. International Journal of Advances in Agriculture Sciences, v.3, p.1-15.

MOUALEUNGANGUE, D.P.; CHEN, T.W.; STÜTZEL, H. A new method to estimate photosynthetic parameters through net assimilation rate-intercellular space $\mathrm{CO}_{2}$ concentration (A-Ci) curve and chlorophyll fluorescence measurements. New Phytologist, v.213, n.3, p.1543-1554, 2017. https://rajpub.com/index.php/jaa
PAL, A.; BHOWMICK, A.R.; YEASMIN, F; BHATTACHARYA, S. Evolution of model specific relative growth rate: Its genesis and performance over Fisher's growth rates. Journal of Theoretical Biology, v.444, p.1127, 2018. https://rajpub.com/index.php/jaa.

SCUDERI, D.; GIUFFRIDA, F.; LEONARDI, C. Growth and visual quality of weeping fig in relation to shading conditions. Journal of Food, Agriculture \& Environment, v.11, p.1828-1832, 2013.

SHIH, T.H.; LIN, S.H.; HUANG, M.Y.; HUANG, W.D.; YANG, C.M. Transcriptome profile of the variegated Ficus microcarpa cv Milky stripe fig leaf. International Journal of Molecular Sciences, v.20, n.6, p.1338, 2019. https:// doi:10.3390/ijms20061338

SKALÁK, J.; VERCRUYSSEN, L.; CLAEYS, H.; HRADILOVÁ, J.; ČERNÝ, M.; NOVÁK, O.; PLACKOVÁ, L.; SAIZ-FERNÁNDEZ, I.; SKALAKOV, P.; COPPENS, F.; DHONDT, S.; KOUKALOV, S.; ZOUHAR, J.; INZE, D.; BRZOBOHATY, B. Multifaceted activity of cytokinin in leaf development shapes its size and structure in Arabidopsis. The Plant Journal, v.97, n.5, p.805-824, 2019. https://doi.org/10.1111/tpj.14261

Van STADEN, J.; UPFOLD, S.J.; DREWES, F.E. Cytokinins in green and yellow leaflets of Schefflera arboricola. South African Journal of Botany, v.60, p.293-294, 1994.

VENEKLAAS， E.J.; SANTOS SILVA， M.P.R.M.; den OUDEN, F. Determinants of growth rate in Ficus benjamina L. compared to related faster-growing woody and herbaceous species. Scientia Horticulturae, v.93, n.1, p.75-84, 2002. https://doi.org/10.1016/S0304$4238(01) 00315-6$

WANG, Z.X.; YANG, Y.M.; XU, P.L.; YU, Y.F.; CHEN, L.; LIU, Y.X.; LI, X.Y.; ZHAO, Y.; QIN, H.Y.; AI, J.; WANG, C.W.; SUN, D. Do Naturally variegated leaves have a high photosynthetic cost? The case of Actinidia kolomikta (Rupr. \& Maxim.) Maxim. Agronomy Journal, v.108, n.1, p.407-414, 2016. https://doi:10.2134/agronj2015.0231

ZHANG, Q.; ZHANG, M.; DING, Y.; ZHOU, P.; FANG, Y. Composition of photosynthetic pigments and photosynthetic characteristics in green and yellow sectors of the variegated Aucuba japonica 'Variegata' leaves. Flora, v.240, p.25-33, 2018. https://doi.org/10.1016/j.flora.2017.12.010 